DOI 10.4467/2543733XSSB.21.020.13813

PIOTR KIMLA

Uniwersytet Jagielloński

\title{
Pulapki realizmu ofensywnego. Uwagi o książce Johna J. Mearsheimera Tragizm polityki mocarstw, przel. P. Nowakowski i J. Sadkiewicz, Kraków 2020
}

Krakowskie wydawnictwo Universitas opublikowało pracę Johna Mearsheimera Tragizm polityki mocarstw w przekładzie Piotra Nowakowskiego i Jana Sadkiewicza ${ }^{1}$. Ten ostatni dał się już poznać jako młody, rzutki redaktor, za którego sprawą trafiają na polski rynek księgarski godne uwagi pozycje o problematyce politycznej. Mam na myśli nie tylko wznowienie pism Stanisława Cata-Mackiewicza, ale również Adolfa Bocheńskiego, Władysława Studnickiego oraz nowe, poszerzone wydanie Dziejów głupoty w Polsce Aleksandra Bocheńskiego. Ostatnia z wymienionych pozycji opatrzona jest przez Sadkiewicza kompetentnym komentarzem².

Jeśli chodzi o pracę Mearsheimera, to towarzyszy mi satysfakcja. Miałem bowiem przyjemność zaznajomić redaktora Sadkiewicza z polityczną teorią chicagowskiego badacza. Uderzało mnie jednocześnie, że Mearsheimerowskie opus magnum nie jest przetłumaczone na język polski, chociaż ukazały się w naszym kraju jego mniejsze prace ${ }^{3}$. Cieszę się więc, że mamy wreszcie tę książkę w języku polskim.

Trzeba przyznać, że thumacze dobrze wywiązali się ze swoich obowiązków. Tylko pozornie bowiem spolszczanie klarownej angielszczyzny Mearsheimera nie nastręcza trudności. Praca w swej pierwszej części (do strony 207) jest pracą teoretyczną, a przekładanie teorii nigdy nie jest sprawą prostą z uwagi na konieczność znalezienia polskich

\footnotetext{
${ }^{1}$ Zob. J. J. Mearsheimer, Tragizm polityki mocarstw, przeł. P. Nowakowski i J. Sadkiewicz, Kraków 2020.

${ }^{2}$ Zob. J. Sadkiewicz, Realizm słabych, [w:] A. Bocheński, Dzieje głupoty w Polsce. Pamflety dziejopisarskie, Kraków 2020.

${ }^{3}$ Por. J.J. Mearsheimer, Dlaczego politycy kłamiq: cała prawda o kłamstwie w polityce międzynarodowej, przeł. G. Łuczkiewicz, Warszawa 2012 oraz Izraelskie lobby w USA, przeł. R. Modzelewski, Warszawa 2011. Współautorem tej drugiej pracy jest Stephen M. Walt. Co ciekawe, główna praca Mearsheimera nie została jak dotąd przetłumaczona na język niemiecki i rosyjski. Wspomniał o tym sam autor w wykładzie na Uniwersytecie Warszawskim, zorganizowanym z okazji ukazania się polskiej wersji The Tragedy of Great Powers Politics. Zob. https://www.youtube.com/watch?v=cjQPT6tWobc, dostęp: 02.03.2020.
} 
ekwiwalentów dla zastosowanej aparatury pojęciowej. Trudność ta z pewnością doskwierała tłumaczom, nawet jeśli sama teoria jest niezwykle przejrzysta.

Omawiane dzieło od momentu jego pierwszego wydania w 2001 roku uchodzi za klasyczną pozycję nie tylko z zakresu teorii stosunków międzynarodowych i teorii polityki w ogólności, lecz także myśli strategicznej. Jest także wykładem historii oglądanej przez pryzmat polityki mocarstw - od 1792 roku (początek wojen z rewolucyjną i napoleońską Francją) do końca XX wieku. Zawiera również spory ładunek prognoz i antycypacji. Polskie wydanie, oparte na najbardziej aktualnej wersji Tragizmu polityki mocarstw, kończy się niezwykle interesującym rozdziałem $C z y$ wzrost potęi Chin doprowadzi do wojny? Analiza chicagowskiego badacza nie napawa optymizmem. Zmierza do konkluzji, że rywalizacja amerykańsko-chińska przybierać będzie coraz ostrzejsze formy, nie wyłączając ograniczonego konfliktu zbrojnego. Tocząca się obecnie wojna handlowa pomiędzy Stanami Zjednoczonymi a Chinami zdaje się potwierdzać Mearsheimerowskie prognozy.

Generalnie praca Mearsheimera spełnia wymogi stawiane naukowym teoriom. Mianowicie obok deskrypcji zawiera także eksplanację oraz pozwala wyprowadzać wnioski na przyszłość. Naturalnie, jak każda teoria, jest uproszczeniem rzeczywistości, które jednak umożliwia oddzielenie tego, co zasadnicze, od tego, co peryferyjne, i ukazanie związków przyczynowo-skutkowych bądź korelacji ${ }^{4}$. Przechodzi przez test logiczny, to znaczy, że wnioski logicznie wypływają z przyjętych założeń, oraz test empiryczny, to znaczy, że teoretyczne założenia i wyprowadzone z nich wnioski zasadniczo wytrzymują konfrontację z faktami. Używam słowa ,zasadniczo”, ponieważ żadna teoria w obrębie nauk społecznych nie wychodzi z konfrontacji z ostrymi próbami testującymi, zaczerpniętymi z empirii bez szwanku, to znaczy w stu procentach pozytywnie. Dla każdej teorii znajdziemy przypadki kontradyktoryjne. Rzecz jasna, im mniej takich przypadków, tym lepsza teoria.

\section{Problematyczność ofensywności Mearsheimerowskiego realizmu}

Realizm Mearsheimera jest realizmem strukturalnym, to znaczy, że dominujący wpływ na zachowanie państw ma silnie deterministyczna struktura systemu, w której państwa funkcjonują, nie zaś, przykładowo, ogólne skłonności ludzkiej natury czy psychologiczne usposobienie przywódców. Jest rzeczą oczywistą, że trudno stworzyć teorię stosunków międzynarodowych lub jakąkolwiek teorię w oparciu o psychiczne predyspozycje poszczególnych polityków. Naturalnie istnieją sytuacje, kiedy wpływ danego polityka jest długotrwały i przemożny. Realizm ofensywny nie jest w stanie uwzględniać tego typu danych i stąd niewytłumaczalne na jego gruncie przypadki. Przykładem, do którego odwołuje się sam Mearsheimer, jest postawa Niemiec w 1905 roku. „Gdy Japonia nieoczekiwanie zadała Rosji druzgocącą klęskę w wojnie lat 1904-1905, wytrącając imperium carskie na pewien czas z europejskiej równowagi sił, ciężar przeciwstawienia się Niemcom spoczął niemal wyłącznie na barkach osamotnionej Francji. Niemcy miały wówczas znakomitą okazję, by zmiażdżyć Francję i znacząco przybliżyć się do sięgnięcia po europejską hegemonię" J. Jak wiadomo, tak się jednak nie stało. To, co dla Mearsheimera i dla realizmu

\footnotetext{
${ }^{4}$ Zob. K.N. Waltz, Struktura teorii stosunków międzynarodowych, przeł. R. Włoch, Warszawa 2010, s. 17.

${ }^{5}$ J.J. Mearsheimer, Tragizm..., s.11.
} 
ofensywnego niewytłumaczalne, daje się, być może, wytłumaczyć wpływem „,ezariańskiej postaci” Ottona von Bismarcka. Ściślej przestrogom, jakie zawarł on w Gedanken und Erinnerungen. Przestrogom sformułowanym dla swych następców przed prowadzeniem polityki próżności i przed próbami wychodzenia poza geograficzne warunki egzystencji narodu. Wszystko po to, by Europa wybaczyła Niemcom wzrost ich znaczenia ${ }^{6}$. W stanowisku Bismarcka uwyraźnia się cecha realizmu politycznego, sytuująca się w opozycji do realizmu ofensywnego Mearsheimera. Tą cechą jest ostrożność, brak awanturnictwa, niezwykle oszczędne posługiwanie się posiadanymi zasobami, nienarażanie tych zasobów (przede wszystkim ludzi oraz ich mienia). Realizm to pietyzm w stosunku do tego, co się posiada w sposób ugruntowany, i nieprzedkładanie owego posiadania nad jakiekolwiek hipotetyczne zyski. To z tego pietyzmu rodzi się siła. Przykładowo, siła pruskiej armii wynikała w bardzo dużej mierze z przeświadczenia żołnierzy, że dowodzący nigdy nie narazi ich życia inaczej aniżeli pod presją najwyższej konieczności. Poszanowanie życia i zdrowia żołnierzy wynikało oczywiście także $\mathrm{z}$ faktu długiego procesu szkolenia, jakim podlegał rekrut. Wiązało się zatem także z oszczędnym wykorzystaniem zasobów ${ }^{7}$. W tym sensie realizm to konserwatyzm, zachowawczość. Realizm to ciagłe przedkładanie tego, co realne, nad to, co potencjalne, gdyż, jak uczył Hegel, to, co istnieje, ma przewagę nad tym, co hipotetycznie mogłoby istnieć, już z tej tylko racji, że istnieje. W zarysowanym kontekście trudno zrozumieć i zgodzić się ze zdaniem Mearsheimera, że „struktura systemu zachęca do wypatrywania okazji do zwiększenia sił własnych i osłabiania rywali, a także korzystania z takich okazji, jeśli tylko spodziewane korzyści przewyższają koszty"». Trudno bez zastrzeżeń przyjać powyższe twierdzenie, że struktura systemu zachęca do zwiększania swych sił i osłabiania rywali. Struktura systemu może być różna. Jeśli w jej obrębie funkcjonuje wiele mocarstw, to przecież ofensywna postawa i próba wzmocnienia się czyimś kosztem spowoduje mobilizację pozostałych mocarstw przeciwko mocarstwu agresywnemu. Teoretycy stosunków międzynarodowych przywołują w tym kontekście tak zwaną „,pułapkę Tukidydesa”. Między innymi ją jak się wydaje, miał na myśli Bismarck, formułując wyżej wskazane zalecenia. Mearsheimerowi chodzi najprawdopodobniej o to, że akumulowanie potęgi jest niezbędne, ponieważ bezpiecznie w systemie może się czuć tylko regionalny hegemon (zdobycie hegemonii światowej leży - wedle chicagowskiego badacza - poza zasięgiem jakiegokolwiek państwa). Tylko regionalny hegemon zainteresowany jest utrzymaniem status quo. Jednakże zdobycie regionalnej hegemonii jest niezwykle trudną sztuką. Zdobycie tej pozycji udało się Stanom Zjednoczonym w dużej mierze, co przyznaje sam autor Tragizmu polityki mocarstw, dzięki wyjątkowo korzystnemu położeniu geograficznemu USA oraz słabości ich sąsiadów. Inne państwa, usiłując sięgnąć po regionalną hegemonię, padły pod ciosami państw, które sprzymierzyły się przeciw pretendentowi określanemu niezmiennie mianem agresora.

\footnotetext{
${ }^{6}$ Por. Otto von Bismarck: reflections and reminiscences, Nowy Jork 1968. Por. także R. Aron, Pokój i wojna między narodami (teoria), przeł. A. Mielczarek, Warszawa 1995.

${ }^{7}$ Por. Frederick the Great, Instructions for His Generals oraz R.R. Palmer, Frederick the Great, Guibert, Bülow: From Dynastic to National War, [w:] Makers of Modern Strategy from Machiavelli to the Nuclear Age, pod red. P. Pareta, Princeton 1986.

${ }^{8}$ J.J. Mearsheimer, Tragizm ..., s. 27.

${ }^{9}$ Por. G.T. Allison, Destined For War. Can America and China Escape Thucydides 's Trap?, Nowy Jork 2018. Praca ta została przetłumaczona na język polski: G.T. Allison, Skazani na wojnę? Czy Ameryka i Chiny unikna pułapki Tukidydesa, przeł. R. Mościcka, M. Wacław, M. Żbikowska, Bielsko-Biała 2018.
} 
Bardzo kontrowersyjnie brzmi również twierdzenie o konieczności korzystania z okazji, jeśli tylko spodziewane korzyści przewyższają koszty. Każdy jednak realista polityczny, dla którego fundamentem działania jest odpowiedzialność za skutki i oszczędność, będzie stał na stanowisku, że niezwykle rzadko można z góry wiedzieć, że korzyści przewyższą koszty. Czyż polityka i wojna jako narzędzie polityki nie rozgrywają się w wielkiej mierze za zasłoną niewiedzy? Politycy i stratedzy podejmują decyzje, nie dysponując pełnią informacji. Tak było $\mathrm{w}$ przeszłości, tak jest obecnie i zdaje się pozostanie w przyszłości ${ }^{10}$. Nie zapobiegnie tej trudności nawet najbardziej skrupulatna kalkulacja sił, skoro zawsze w grę wchodzi trudne do wyważenia Clausewitzowskie „napięcie woli”. Nie zapobiegnie tej trudności najbardziej zaawansowana technika, bo także ona nie potrafi szacować „napięcia woli”, które mieści się w ludzkich umysłach i przekłada na determinację w dążeniu do celu i determinację w walce. Mearsheimer słusznie twierdzi, że nie sposób zyskać pewność co do czyichś intencji, szczególnie w dłuższym okresie. Podobnie jednak nie sposób z całkowitą pewnością lub nawet $\mathrm{z}$ dużą dozą pewności orzekać o wyniku sporu politycznego czy wojny pomiędzy państwami, szczególnie gdy są to państwa o zbliżonym potencjale.

Można odnieść wrażenie, że działanie realisty ofensywnego w sferze polityki biegnie w zgodzie z myślą Annie Sanders (wypowiedzianą w odniesieniu do życia prywatnego): „lepiej żałować, że się coś zrobiło, niż żałować, że się czegoś nie zrobiło”. Tego typu podejście jednakże ściaga na jego głowę zarzut politycznego awanturnictwa. Realista ofensywny to wieczny rewizjonista (chyba że jest regionalnym hegemonem, o czym wyżej), wieczny wichrzyciel, destruktor stabilizacji, wiarołomny sojusznik. Rewizjonizm, próby przekształcania układu sił w systemie międzynarodowym, tak by wzmacniał naszą potęgę, muszą z konieczności pociagać za sobą deptanie wypracowanych reguł, ucieleśnianych przez instytucje. Podkreślanie przez Mearsheimera, że dobry realista szanuje instytucje ${ }^{11}$ i co za tym idzie - reguły, sytuuje się w opozycji do ciągłych zmian w systemie, do ofensywności jego teorii. Ofensywność musi przecież nieraz wieść do wywracania reguł.

Problematyczny jest także skrajny determinizm, fatalizm Mearsheimerowskiej teorii. Wspomniałem wcześniej, że Mearsheimer stoi na stanowisku nieuchronności konfliktu na linii Stany Zjednoczone - Chiny, o ile Państwo Środka będzie nadal tak dynamicznie się rozwijać. Mearsheimer nie bierze pod uwagę argumentów, że „pułapka Tukidydesa” nie jest tożsama $\mathrm{z}$ fatalizmem. Bywały bowiem sytuacje, gdy, między innymi dzięki usilnym zabiegom dyplomatycznym, udawało się uniknąć konfliktu pomiędzy wzrastającą w siłę potęgą a potęgą strzegącą status quo, między rising power a ruling power - mówiąc słowami wspomnianego wyżej Grahama Allisona. Nie ulega kwestii, że polityka jest w dalece większej mierze domeną determinizmu aniżeli domeną woluntaryzmu. Znawcy polityki, szczególnie ci, którzy sami ją uprawiali, niejednokrotnie zwracali uwagę na ten zasad-

${ }^{10}$ Dobitnym potwierdzeniem jest próba odsunięcia od władzy Michaiła Gorbaczowa - ówczesnego prezydenta Związku Radzieckiego, która przeszła do historii jako pucz Janajewa (sierpień 1991 roku). Opisujący go z perspektywy amerykańskiej Brent Scowcroft ukazuje skąpość informacji, jakie on - jako doradca prezydenta USA do spraw bezpieczeństwa narodowego - i sam prezydent USA mieli do dyspozycji, gdy musieli podejmować brzemienne w skutki decyzje. Zob. HBO History Makers Series: A Conversation with Brent Scowcroft, https:// www.youtube.com/watch?v=5-aaSp7J0A0, dostęp: 03.03.2020.

${ }^{11}$ Zob. J.J. Mearsheimer, The Great Delusion, wykład na Carleton University 30 stycznia 2020 roku, https://www.youtube.com/watch?v=nZVIaXFN21U, dostęp: 03.03.2020. 
niczy fakt. Chociaż przestawienie polityki na inne tory nie jest sprawą tak łatwą, jak to się zdaje ludziom niepoświęcającym polityce dostatecznej uwagi, to jednak leży to $\mathrm{w}$ granicach ludzkich możliwości. Determinizm cechujący domenę polityki nie jest determinizmem skrajnym. Nie jest determinizmem stoików, dla których wolność to tylko uświadomiona konieczność. Nie jest determinizmem Barucha Spinozy, w oczach którego człowiek ma tyle wolności, co rzucony kamień, któremu się wydaje, że jest wolny, bo sam spada. Determinizm sfery politycznej nie jest fatalizmem. W politycznej sferze jest miejsce na podejmowanie decyzji głupich i krótkowzrocznych, ale, z drugiej strony, jest także przestrzeń do rozstrzygnięć roztropnych i dalekowzrocznych. Nie wszystko jest z góry przesądzone. Innymi słowy, także na polu polityki istnieje ludzka wolność. Mearsheimerowska teoria zdaje się nie brać tego pod uwagę.

W innym miejscu wskazywałem problematyczność określania ofensywnego realizmu Mearsheimera mianem realizmu w polityce ${ }^{12}$. Na gruncie wypracowanego przeze mnie ujęcia realizmu politycznego dyskusyjne jest propagowanie poszukiwania dominacji w polityce, nawet jeśli miałaby to być „tylko” dominacja regionalna. W moim przekonaniu realizm nierozerwalnie wiąże się ze świadomością swoich własnych ograniczeń, z odkryciem „momentu Machiavellego”, mówiąc językiem J.G.A. Pococka. Wiąże się z przekonaniem, że trwała dominacja międzynarodowej sceny jest niemożliwa. A jeśli jest niemożliwa, to logika nakazuje wyciągnięcie jednego zasadniczego wniosku. Skoro nie mogę zdominować i wyeliminować politycznych partnerów-rywali, to muszę nauczyć się z nimi koegzystować, muszę poszukiwać dróg porozumienia. To rozumowanie doprowadza realistów najczęściej na konserwatywne (a nie rewizjonistyczne!) pozycje obrońców pokoju, przeciwników wojny, przeciwników nieliczącego się z rzeczywistością politycznego awanturnictwa i agresji. Żeby rzecz postawić jasno: w prezentowanym przeze mnie modelu realizmu nie chodzi o to, że posiadanie potęgi czy nawet hegemonii jest czymś niepożądanym. Winno się unikać ekspansywnych, imperialistycznych zapędów, ponieważ ostatecznie są one nie do zrealizowania. Wszystkim stronom uwikłanym w tego typu politykę przynoszą one jeśli nie całkowite zniszczenie, to zubożenie. Naturalnie powtarzam rozumowanie, które już kiedyś sformułowałem, gdyż nie zmieniłem zdania.

Piotr Kimla, dr hab., prof. UJ; studia politologiczne i podyplomowe filozoficzne ukończył na Uniwersytecie Jagiellońskim. Pracuje w Instytucie Nauk Politycznych i Stosunków Międzynarodowych UJ. Dwukrotny stypendysta Fundacji na rzecz Nauki Polskiej; wykładał gościnnie na Uniwersytecie w Padwie, na Uniwersytecie Karola w Pradze, Uniwersytecie w Heidelbergu, Uniwersytecie Kreteńskim. Zajmuje się historią myśli politycznej i strategicznej, w szczególności zagadnieniem realizmu w polityce w wymiarze polskim i europejsko-amerykańskim. Redaktor prac naukowych, autor książek, rozdziałów drukowanych w pracach zbiorowych, artykułów naukowych w polskoi obcojęzycznych czasopismach. Najważniejsze publikacje: Kiedy czas staje i czas nie ma końca. Idee polityczne w eseistyce T.S. Eliota, Kraków 2003, Historycy-politycy jako źródto realizmu politycznego, Kraków 2009, Political Realism - Theory and Practice, Kraków 2018 (Nagroda im. Jana Baszkiewicza).

\footnotetext{
${ }^{12}$ Por. P. Kimla, Political Realism - Theory and Practice, Kraków 2018.
} 